\title{
Community role of civil society in the household waste management and urban farming
}

\author{
Dwi A. Nirwana, John V. Lewi, M. Shoful Ulum, Happy R. Santosa \\ Dept. of Architecture Institut Teknologi Sepuluh Nopember, Surabaya, Indonesia

\section{Email address:} \\ Towet13@ymail.com (Dwi A. Nirwana),john_lewi@hotmail.com (John. V. Lewi), sohofuru@gmail.com (M. Shoful Ulum), \\ happy_rs@arch.its.ac.id (Happy R. Santosa)
}

\section{To cite this article:}

Dwi A. Nirwana, John V. Lewi, M. Shoful Ulum, Happy R. Santosa, Community Role of Civil Society in the Household Waste Management and Urban Farming. International Journal of Environmental Monitoring and Analysis. Vol. 2, No. 1, 2014, pp. 45-49. doi: $10.11648 /$ j.ijema.20140201.15

\begin{abstract}
Sustainable development becomes a thought that can be realized by applying the principles of eco-friendly living. One of the real forms of life that is environmentally friendly is household waste management and urban farming. It is necessary for the activity and awareness of the public to participate in developing waste management system and urban farming to maintain the environmental conditions as well as to improve the local economy. The method used in this study is case study method. Data collection techniques used physical observation, interviews, and literature. The result shows that the community has a big role in achieving sustainable development.
\end{abstract}

Keywords: Sustainable Development, Waste Management, Urban Farming

\section{Introduction}

Semolowaru Elok RT 2 RW 8 is one of the regions that make serious efforts in reducing the effect of housing activities toward its surrounding environment by processing the household waste and developing the urban farming technique which in this particular case, mushroom farming. An infrastructure known as garbage bank is built to facilitate the citizen to process their household waste. On the other hand, an infrastructure bolstering up the urban farming has also being operated under the citizen's own management. Besides the physical development, in order to achieve sustainable development, and to make positive effect toward the citizen's economics, it also needs nonphysical development. In this case, it involves the improvement of soft skills, such as management and marketing.

This research is to analyze the role of sustainable development for the improvement of economics of the people of Semolowaru Elok RT 2 RW 8. And to understand the factors that contribute or impede the application of sustainable development and the factors that impede the development of the citizen's economics.

\section{Research Area}

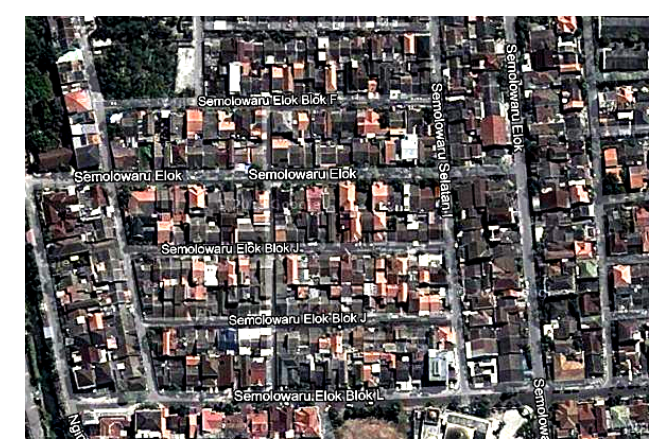

Figure 1. The Sitemap Location (from Google Maps 2013 ).

The location of study is at Semolowaru Elok RT 2 RW 8 as shown in Fig. 1. Most of the areas are houses with small garden, and some part of the area is small herb parks. This settlement is often used as reference for students who want to know more about how to manage waste, farming and arranging good community.

Sustainable development is a development process that needs cost, but there are ways to create an effective and low cost sustainable development, such as:

1. Maintain the natural environment

In terms of architecture and their environment, nature and environments is a key factor in design and the architecture itself. That is why this factor needs to be concerned because the environment problems are also increasing. Natural 
environment is also determines the quality of the area and the community behavior inside. With a well-preserved natural environment shows the moral concerns of society on the surrounding environment.

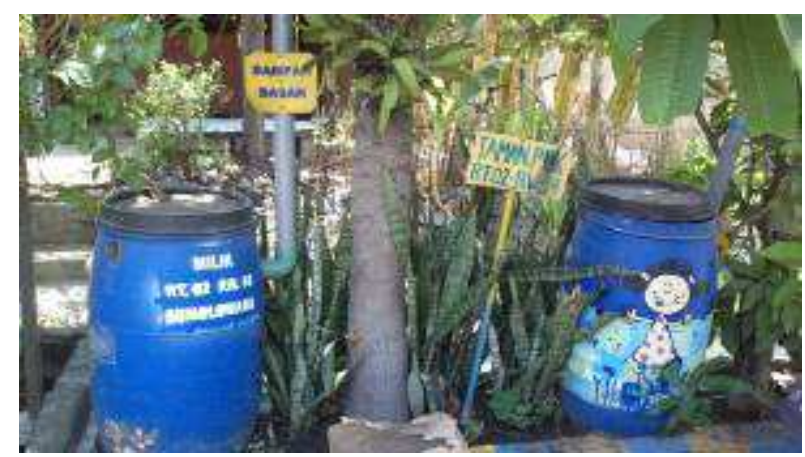

Figure 2. Rubbish bin.

The community support in the study location is good especially for the natural environment. This support can be seen from how the living environment looks well organized. The efforts done by the community like planting together, waste separation, also making center for environment problems solving as shown in Fig.2.

2. Smart calculation for economic development

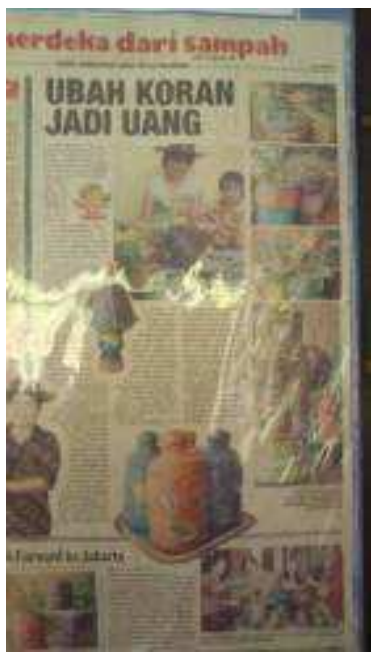

Figure 3. Local newspaper took a story of the settlement.

In this case is how community could estimate the progress in economic factor for community itself. How people could estimate the cost of water, electricity, and other fees that must be smaller than fees from the community itself in development.

In Semolowaru RT 2 RW 8, the community is already having a smart careful calculation in terms of economic development. They sell recycling stuffs from waste generated by the community. Utilization of old news paper, and other waste materials were done as the effort to improve the quality of economic communities themselves. They were also doing cultivation of several plants such as mushrooms. Their activities were noted at local newspaper as shown in Fig. 3 and in several photos in Fig. 4.

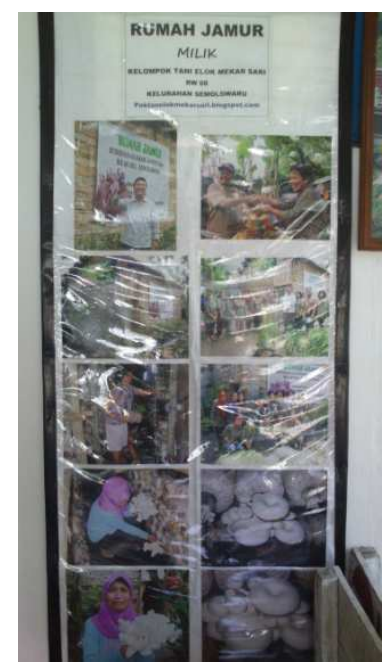

Figure 4. Photos of community's activity.

\section{Support local farmer}

By supporting local farming, community can also raise their living standards through the fulfillment of the people need. Local agricultural economy also can improve the quality of a region by selling back the results of the farming activity in the community outside of the area of settlement.

In Semolowaru, the development of local farm is exploited more for economic problems that is to sell back the results - agricultural products (or in this case more precisely cultivated) mushroom in the area.

4. Build by mix-use, pedestrian oriented and eco-communities

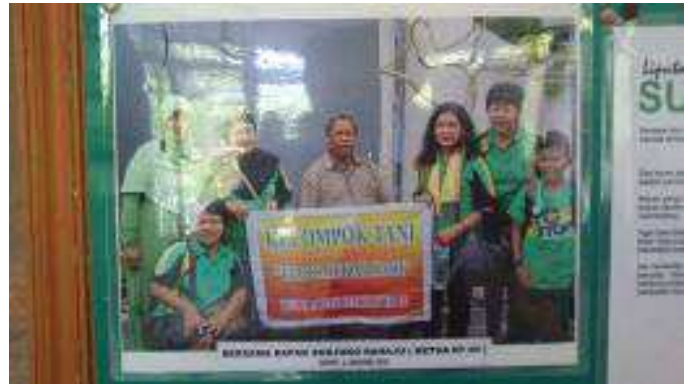

Figure 5. Photo member of Farm Group.

Eco-community is one thing that can support sustainable development in environment. Through eco-community there are special concern done by community in surround environment and also the improvement of living quality of the community.

Building mix-use is the building that can be use or functioned in a variety of functions. This is crucial as the sustainable development of each existing building and the area should benefit as much as possible. With the mix-use buildings - the variety of activities can be done in one building / area. Eco community is also support sustainable development in terms of environment. With the eco community there may be a particular concern in the community who do care about the environment and also in terms of improving the quality of life in society. 
Semolowaru RT 2 RW 8 is a residential area that most of the existing building is housing. There is a post building that that can be use as a gathering place for communities to gather community activities that they do, so that the building could be in the category of buildings mix - use. The people at Semolowaru RT 2 RW 8 itself also has a community they call eco farmer groups, i.e. community focused on improving the quality of people in Semolowaru RT 2 RW 8 itself. Farmer groups now called Mekar Sari sea farmer.

5. Using better transportation, communication, and production system

The usage of good facility is also one of the factors of sustainable development, in this term is how community could take advantage and responsive to this developing era to improve the living quality of the indigenous people.

This kampung (Semolowaru RT 2 RW 8) is already use modern communication system by promote their settlement using blog or personal website. This blog shows their activity and their goodness. Their settlement became more popular after shows online. With the use of more advanced communications technology, the result of production from the region itself can be more recognized by the public and can directly improve the quality of life of the people in Semolowaru RT 2 RW 8 itself.

6. Maximizing conservation

In sustainable development, the conservation attempt include how to optimize the land for common good, like farming, reforestation, or special need for community itself. By this utilized land, people can do business in the improvement of living standards.

Semolowaru region RT 2 RW 8 itself is a residential area, so most of the land is housing, land that can be used for the conservation is the sidewalk and some parts of the river. Most of the people do their work in the home of the community. The land that can be used is land in RW hall.

7. Supporting renewable energy

Renewable energy is an attempt to save the age of world. The age of world that continuously decreasing because of fossil fuel which is environmentally harm and limited is in need to be paid attention. That is why the utilization of renewable energy is compulsory for sustainable development that will keep exist and needed unlimited resources.

In this case the area Semolowaru RT 2 RW 8 itself has not been sought for the use of renewable energy. People are still using energy that is supplied by the government like electricity, water, and so on.

8. Use $3 \mathrm{R}$ program

3R program include: Reduce Reuse and Recycle. This attempt is so important because of the growing problem of garbage piling up in the earth. In sustainable development, garbage is an important problem that must be carried on. Utilization of garbage into useful products is one of the main points of $3 \mathrm{R}$ itself. It is how to reduce the garbage by using its own garbage as useful stuff but in different form.

Semolowaru region RT 2 RW 8 is already using the $3 R$ system. This is demonstrated by the separation of garbage that has been done of wet waste and dry waste. The business community itself is doing the manufacture of handicrafts from materials that originally been unused and used as new items that have a sale value as shown in Fig.6. This effort is also decreasing waste generated and also increasing the economic level of the society and also most importantly to preserve the environment by minimizing garbage produced by the community itself.

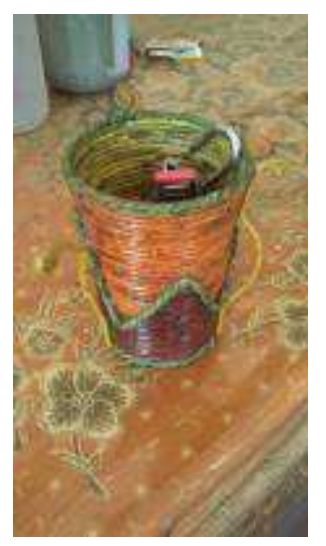

Figure 6. Handcraft from usable stuff.

9. Force education to manage the environment

Education is a fundamental factor in sustainable development because good education can lead to better educated people that can really think and care about sustainable development problem as it needed.

In Semolowaru RT 2 RW 8, there is no formal education in environmental management yet. The education received by the community is informal education that was studied together in terms of how to take care of the existing environment so that all citizens Semolowaru RT 2 RW 8 itself has a sense of ownership in the existing environment in the area.

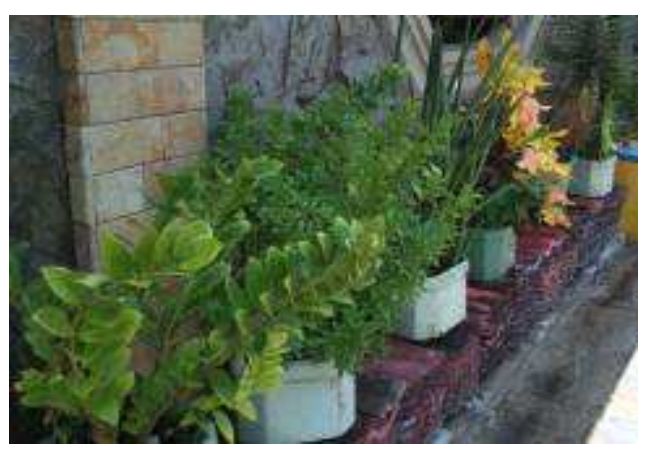

Figure 7. Plant at Semolowaru.

\section{Results and Discussion}

Sustainable development is a continuous process of development that optimizes the benefits of natural resources and human resources by means of harmonizing human activities in accordance with the ability of natural resources to sustain it.

Environmentally sustainable development goal, include: 
- Reduce the burden of environmental pollution

- Implement policies to reduce the rate of environmental degradation

- Establish environmental considerations in the implementation of conservation and development planning

- Improve compliance of the people involved in development to maintain the quality of the environment

- Achieve prioritization of governance principles in the management of human resources.

- Achieve an increase in the capacity of environmental management.

Meanwhile, environmental management aims are:

- Achieve harmony between human relationships with the environment by means of creating a fully Indonesian man.

- The wisely controlled use of natural resources

- Realization of Indonesian as environmental adviser

- Implementation of environmental based development for the benefit of present and future generations.

- The protection of the state against the impact of activities from other countries which cause damage and environmental pollution

The use of environmentally friendly materials will be very useful for nature and people and make an excellent balance. An architect must not rule out the materials they use because it will have influences to the nature, ranging from the impact that would occur if architects use materials that would destroy nature in the future.

The principles for appropriate use of building materials are as follows:

- Using raw materials, energy, and water to a minimum.

- The smaller the energy requirements in production and transportation, the less waste generated.

- Building materials are produced and used in such a way so that it can be returned into the chain materials (recycled).

- Avoid the use of hazardous materials (heavy metals, chlorine) as building materials.

- Materials used should be strong and durable.

- Building materials or parts of the building should be easily repaired and replaced.

\section{Sustainable Development Approach Trough Social, Economic and Materials Aspects}

\subsection{Material Aspect}

Selection of materials for construction becomes an important thing to reduce the negative impact of city development on the environment. Materials with high durability and capable to be reused or recycled become the main consideration for sustainable development. The case study conducted in Semolowaru RT2 RW8 shows the selections of construction materials have not noticed the points mentioned above yet since available fund become the main consideration.

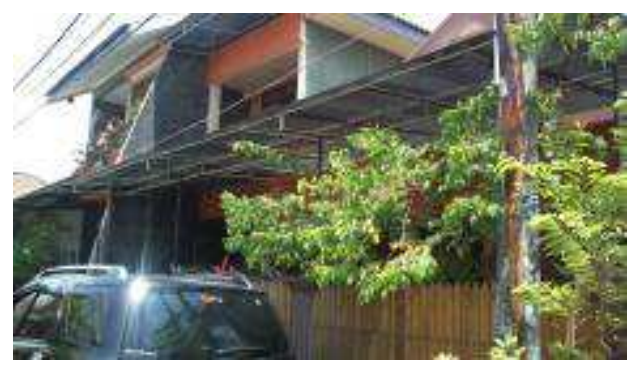

Figure 8. Example from House RT $2 R W 8$.

It can be mentioned here that the material is an important factor in sustainable development. Since the material will affect the capability of the building to survive for a long period of time. Semolowaru Elok RW8 RT2 existing buildings as shown in Fig. 8 still have less attention to their materials.

\subsection{Social Aspect}

Maximum utilization of natural resources in order to achieve sustainable development is influenced by the awareness of each individual to make eco-friendly lifestyle as a necessity. The existence of a social community within a society can increase the rate of adoption of sustainable development. Through the community, information and knowledge about sustainable development can be spread quickly and effectively. The case study conducted in Semolowaru RT2 RW8 shows the role of community in encouraging the awareness for eco-friendly living such as:

1. Managing household waste into fertilizer. Fertilizer produced from waste is used to fertilize the gardens in RT2 RW8 as shown in Fig. 9.

2. Provide trash cans for different types of waste, such as the separation of organic waste, inorganic, and plastic

3. Conducting independent environmentally friendly business training such as mushroom cultivation training, cricket cultivation training, and seaweed based soap manufacture training.

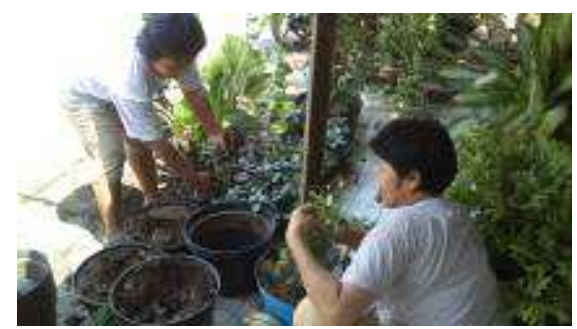

Figure 9. Citizen from $R T 2 R W 8$ Semolowaru put fertilizer on the plants.

\subsection{Economic Aspect}

Urban farming has big role in urban society life. Limited farming field can be solved by the most updated technique. Urban farming has such capability to keep the stability of city ecosystem which is full of buildings and also increase citizen economic by the profit of its product's sales. The study case shows the positive impacts of urban farming toward the increasing of citizen prosperity. It showed by the 
improvement on citizen income. Mushroom cultivation and cricket cultivation managed by citizen community get positive response from consumers, whether individual or retail businesses. Product promotions are nicely done through community blog that provide the most updated news of their activities. As shown in Fig. 10 until Fig. 13, they develop each of citizen's soft skills.

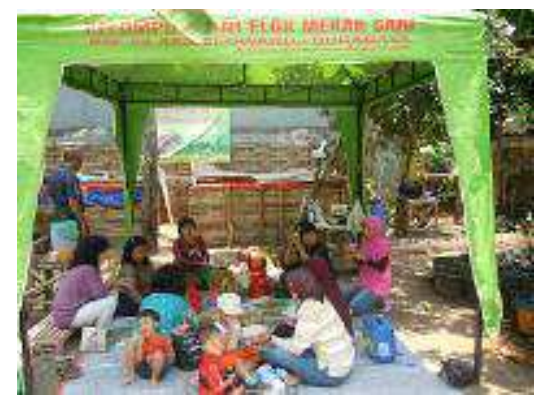

Figure 10. Activities: the making of sea weeds soap (http://poktanelokmekarsari.blogspot.com).

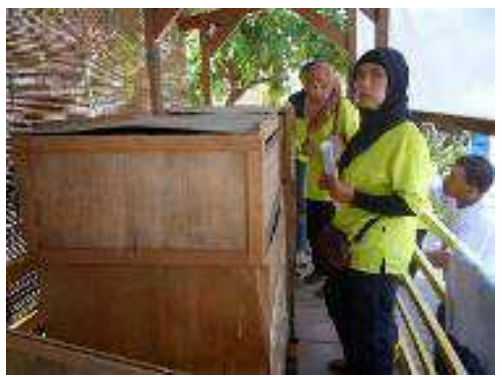

Figure 11. Training cricket's cultivation (http://poktanelokmekarsari.blogspot.com).

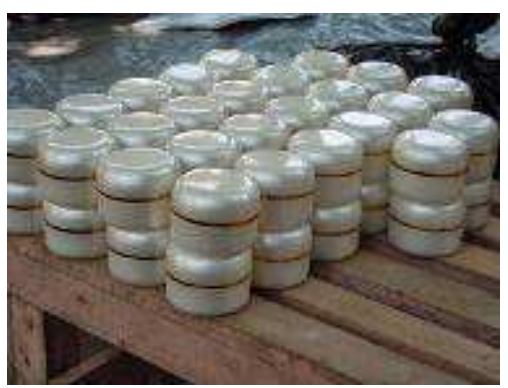

Figure 12. The soap product ready to market (http://poktanelokmekarsari.blogspot.com).

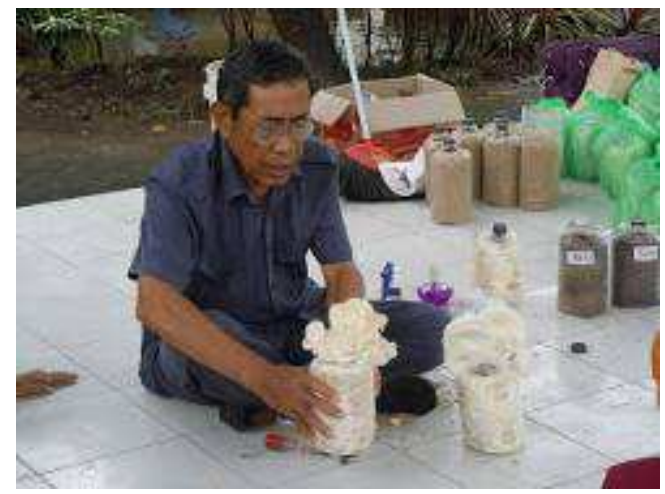

Figure 13. Cultivation training of oyster mushroom (http://poktanelokmekarsari.blogspot.com).

\section{Conclusion}

Community, as mass activator, has a big role in order to achieve sustainable development. Through workshops, and seminar, citizens are able to develop their skill and knowledge about sustainable development especially in economic and social aspect.

Some positive impacts of urban farming that showed at Semolowaru RT 2 RW 8 are:

- It has big contribution to environment rehabilitation.

- Creating clean city by applying 3R (reuse, reduce, recycling).

- Increasing environment quality by producing $\mathrm{O}_{2}$.

- Increasing citizen prosperity.

\section{References}

[1] Groat, Linda, Architectural Research Methods. Canada: John Wiley \& Sons. 2002.

[2] http://poktanelokmekarsari.blogspot.com/

[3] http://urbanfarmingmania.blogspot.com 